\title{
GENETIC DIFFERENTIATION BETWEEN NOBLE CRAYFISH, ASTACUS ASTACUS (L.), POPULATIONS DETECTED BY MICROSATELLITE LENGTH VARIATION IN THE RDNA ITS1 REGION.
}

\author{
L. EDSMAN (1), J.S. FARRIS (2), M. KÄLLERSJÖ (2), T. PRESTEGAARD (1)
}

(1) Institute of Freshwater Research, National Board of Fisheries, SE-17893 DROTTNINGHOLM, Sweden.

(2) Laboratory of Molecular Systematics, Swedish Museum of Natural History, SE-10405 STOCKHOLM, Sweden.

Reçu le 04 février 2002

Accepté le 04 novembre 2002

Received 04 February, 2002

Accepted 04 November, 2002

\begin{abstract}
The Internal Transcribed Spacer (ITS) region of the nuclear ribosomal repeat was investigated in the search for a suitable genetic marker for population studies of the noble crayfish Astacus astacus (L.). DNA sequencing revealed the presence of two microsatellite insertions in ITS1. By designing highly specific PCR primers, adjacent to one of the insertions, we were able to use fragment analysis to explore the variation of the insertion in 642 specimens from 17 populations of crayfish from Sweden and former Yugoslavia. A new statistical test, the Population Divergence Test, was developed to assess statistical significance of divergence between populations. This test does not assume Mendelian inheritance. Our results demonstrate that different populations often produce characteristic fragment patterns, and that most, but not all, populations are genetically distinct, with high significance. The populations that cannot be significantly differentiated are situated in close geographic proximity to each other and belong to the same main river system, probably reflecting that these populations have had recent contact and that gene flow has occurred.
\end{abstract}

Key-words : genetic diversity, populations, crayfish, Astacus astacus, microsatellites, ITS, conservation, Population Divergence Test.

\section{DIFFÉRENCIATION GÉNÉTIQUE ENTRE LES POPULATIONS D'ÉCREVISSE ASTACUS ASTACUS (L.) DÉTECTÉE PAR LA VARIATION DE LONGUEUR D'UN MICROSATELLITE DE LA RÉGION RIBOSOMIQUE NUCLÉAIRE ITS1.}

\section{RÉSUMÉ}

La région ITS du ribosome nucléaire a été examinée pour trouver un marqueur génétique approprié pour l'étude des populations d'écrevisse Astacus astacus (L.). Les séquences d'ADN révèlent la présence de deux insertions de microsatellite dans l'ITS1. 
En définissant des amorces d'amplification spécifiques, adjacentes à l'une des zones d'insertion, nous avons pu utiliser une analyse de fragment pour explorer la variation de l'insertion de 642 spécimens répartis dans 17 populations d'écrevisse de Suède et d'exYougoslavie. Une nouvelle méthode d'analyse statistique, le «Population Divergence Test » a été développée pour étudier la significativité statistique de la divergence entre les populations. Ce test ne suppose pas une hérédité mendélienne. Nos résultats démontrent que les différentes populations présentent souvent des structures de fragments caractéristiques, et que la plupart des populations sont génétiquement distinctes, avec une forte significativité. Les populations qui ne peuvent pas être significativement différenciées sont géographiquement très proches les unes des autres et appartiennent au même système fluvial principal, indiquant probablement un flux génique récent entre les populations.

Mots-clés : diversité génétique, populations, écrevisse, Astacus astacus, microsatellites, ITS, conservation, Population Divergence Test.

\section{INTRODUCTION}

Both historically and today there has been a great interest in freshwater crayfish in Sweden and the crayfish fishery constitute a substantial social, cultural and economic value. In Finland fossil remains of noble crayfish Astacus astacus (L.) (Decapoda: Astacidae), have been found dating back to $3000-1000$ B. C., thus suggesting that it is native to the country and not introduced by man. Such fossil records have not been found in Sweden and whether the noble crayfish is a natural immigrant or was once stocked has been discussed (SKURDAL et al., 1999). Most probably the species immigrated to the country during the Ancylus time period $(9500-8000$ B. C.) after the last glaciation (SVÄRDSON, 1972; ODELSTRÖM and JOHANSSON, 1999). It is regarded as the only native freshwater crayfish species in Sweden by the authorities and its presence is first documented in the $16^{\text {th }}$ century.

Noble crayfish was earlier confined to the southern parts of the country but through extensive stocking over the last 500 years, the range has been extended northwards to also include mainly running waters along the East Coast, all the way up to the Finnish border. It is estimated that Sweden had 30000 populations of noble crayfish at the beginning of the $20^{\text {th }}$ century and that only $5 \%$ of these now remain (FISKERIVERKET, 1993). The noble crayfish is threatened as a species mainly because of the disease crayfish plague (Aphanomyces astaci Schikora), acidification, pollution and competition from the introduced signal crayfish Pacifastacus leniusculus (Dana). For this reason, the noble crayfish is classified as vulnerable on the national Swedish red list for endangered species (GÄRDENFORS, 2000). The species already belonged to this category on the international IUCN red list (GROOMBRIDGE, 1994). An action plan for the conservation of the noble crayfish has also been produced (FISKERIVERKET and NATURVÅRDSVERKET, 1998). One of the important actions in the conservation plan is to reintroduce noble crayfish into lakes that used to hold populations of crayfish. It has then become important to study the genetic variation between populations from different parts of the country. If there are genetic differences, this should influence regulations and practices for stocking so that restocking does not constitute a threat for the biological diversity by depleting genetic variation.

Earlier genetic surveys, using isozyme electrophoresis, have usually shown low levels of heterogeneity between populations of freshwater crayfish and this is also the case in most crustaceans studied (HEDGECOCK et al., 1982). Electrophoretic studies on the related native European species Austropotamobius pallipes (Lereboullet), have shown potential in assessing the genetic structure of Swiss and Italian populations, but the interpretation of the results in connection to the geographic distribution of the populations 
is not quite clear (LÖRTSCHER et al., 1997). A study of noble crayfish in Norway (FEVOLDEN and HESSEN, 1989) revealed some genetic variation between populations. In contrast to this, a study on four noble crayfish populations from Sweden and Poland, investigating 29 loci, did not reveal any interpopulation differentiation at any loci (AGERBERG, 1990).

In the last ten years molecular genetic markers with a higher degree of genetic variability have become available and this has made it easier to better evaluate genetic divergence between crayfish populations (CRANDALL, 1997; SOUTY-GROSSET et al., 1997; SOUTY-GROSSET et al., 1999). Recent studies, using molecular markers like mtDNA for $A$. pallipes (GRANDJEAN et al., 1997; GRANDJEAN and SOUTY-GROSSET, 2000), a combination of allozymes and mtDNA for A. pallipes (LARGIADER et al., 2000), RAPD-PCR for $A$. astacus (SCHULZ, 2000) and for $A$. pallipes (GOUIN et al., 2001), AFLP for Orconectes sp. (FETZNER and CRANDALL, 1999), and microsatellites for A. pallipes (GOUIN et al., 2000) have been successful in studying population characterization and geographically correlated variation. Apart from the study by SCHULZ (2000), molecular techniques have not been applied when studying the population genetic structure of noble crayfish $A$. astacus.

In order to identify a genetic marker suitable for population studies of the noble crayfish $A$. astacus, occurring in Sweden, we set out to investigate sequence variation in the internal transcribed spacer (ITS) region of the nuclear ribosomal repeat. The ITS region of the nuclear ribosomal repeat has frequently been used in phylogenetic studies of plants and fungi (e.g. ELDENÄS et al., 1998; WHITE et al., 1990; GARDES and BRUNS, 1993; BALDWIN et al., 1995) but, until recently (SCHILTHUIZEN et al., 2001), comparatively few animal studies have focused on this region.

In the nucleus, ribosomal genes occur as tandemly repeated units, consisting of a transcribed region followed by an intergenic spacer (IGS). The transcribed region is in turn composed of an external spacer (ETS) at the 5' end, followed by three genes coding for the ribosomal subunits (18S, 5.8S and 28S), separated by the two spacers, ITS1 and ITS2. In animals, the number of repeats typically varies between 100-500, and the repeats are thought to evolve together, a phenomenon mostly referred to as concerted evolution (ZIMMER et al., 1980). This process is thought to result in sequence homogenization among repeats. This effect is most prominent in the conserved subunits of the transcribed portion whereas in the more rapidly evolving spacers, most notably the IGS, polymorphisms among repeats have been reported on several occasions (e.g. POLANCO et al., 1998). Intragenomic variation has also been found in the internal transcribed spacers (e.g. SUH et al., 1993; TANG et al., 1996).

We soon found that sequencing the ITS region from $A$. astacus was difficult. Most attempts resulted in prematurely terminated reads due to the occurrence of two dinucleotide GA-repeats in ITS1. Similar microsatellite-like insertions in the ITS have recently been reported from other freshwater crayfish. HARRIS and CRANDALL (2000) investigated ITS inter- and intraspecific variation among specimens of Orconectes and Procambarus, and found multiple « microsatellites » in both ITS1 and ITS2. They noted that the insertions displayed considerable intragenomic variation that obscured phylogenetic relationships. They also pointed out that since the insertions were found in multiple copy regions they should not be statistically treated as microsatellites, i.e. they should not be assumed to be codominant Mendelian markers.

When we compared ITS1 sequences from individuals from different populations of A. astacus, we found that one of the dinucleotide repeats, situated near the 5 ' end, appeared to be constant in length within populations, but varied between them in a fashion that made it potentially useful as a genetic marker. We decided to further investigate the variation by designing highly specific PCR primers flanking this « microsatellite ». In a pilot 
study of four populations, we found that even though there was considerable intragenomic variation, the populations could be distinguished from each other by distinctive fragment patterns. We then extended our study to include a total of 15 populations from different localities in Sweden. This paper presents the result of that study and introduces a statistical approach to test for significant genetic variation among populations that does not assume a codominant Mendelian inheritance.

\section{MATERIAL AND METHODS}

\section{Specimens}

All Swedish A. astacus specimens were collected 1996-1999 by the National Board of Fisheries, Sötvattenslaboratoriet (SÖL) or by local fishermen under the supervision of SÖL. The locals were interviewed about the history of the crayfish populations and whether crayfish were known to have been introduced. Fifteen populations from different localities in Sweden were represented by 21-49 specimens each (Table I). Two populations from former Yugoslavia, Crupaco (mc) and Slano (ms), were also included to compare allele length in geographically distant populations. 76 individuals from the two Montenegro populations were obtained from commercial fishery. For further comparison we also extracted DNA from six specimens of $P$. leniusculus, and from a single individual of Astacus leptodactylus (Esch.), Pandalus borealis Krøyer and Nephrops norvegicus (L.), respectively. A complete list of specimens and localities is provided in Tables I and II. A map of the localities is found in Figure 1.

\section{Table I}

Origin and number of specimens used in the analyses.

\section{Tableau I}

Origine et nombre d'individus analysés.

\begin{tabular}{lllc} 
Lake/River & Abbreviation & County & Number of specimens \\
\hline Aspen & as & Sörmland & 49 \\
Bornsjön & bo & Sörmland & 44 \\
Burträsk & bu & Norrbotten & 40 \\
Gotland & go & Gotland & 34 \\
Gransjön & gr & Dalsland & 45 \\
Ljungan & lj & Medelpad & 21 \\
Lockvattnet & lo & Sörmland & 22 \\
Malån & ma & Dalsland & 26 \\
Molkom & mo & Öland & 37 \\
Montenegro & mc & Crupaco,Yugoslavia & 44 \\
Montenegro & ms & Slano, Yugoslavia & 32 \\
Nättrabyån & nä & Blekinge & 22 \\
Råneälven & rå & Norrbotten & 45 \\
Teåkersjön & te & Dalsland & 45 \\
Tjörnarpasjön & tj & Skåne & 45 \\
Tomtasjön & to & Uppland & 45 \\
Åsebyälven & ås & Värmland & 46 \\
\hline
\end{tabular}


Table II

The localities of the Swedish crayfish populations studied, main drainage system, lake size, an estimate of their originality and the origin of known stockings, stocking year and sampling occasions.

Tableau II

Localités des populations d'écrevisse étudiées, du système fluvial principal, superficie du lac, estimation sur l'origine des stocks connus, âge des stocks et périodicité des échantillonnages.

\begin{tabular}{|c|c|c|c|c|c|c|}
\hline Locality & $\begin{array}{l}\text { Main river } \\
\text { system }\end{array}$ & $\begin{array}{l}\text { Lake size } \\
\text { (hectares) }\end{array}$ & $\begin{array}{l}\text { Known } \\
\text { stockings } \\
\text { from other } \\
\text { populations }\end{array}$ & $\begin{array}{l}\text { Stockings } \\
\text { originating from }\end{array}$ & $\begin{array}{l}\text { Stocking } \\
\text { years }\end{array}$ & $\begin{array}{l}\text { Sampling } \\
\text { occasions }\end{array}$ \\
\hline $\begin{array}{c}\text { River } \\
\text { Råneälven }\end{array}$ & Råneälven & - & yes & $\begin{array}{l}\text { South Sweden } \\
\text { (Småland), } \\
\text { North Finland }\end{array}$ & $1948-1960$ & 1 \\
\hline $\begin{array}{l}\text { Lake } \\
\text { Burträsk }\end{array}$ & Bureälven & 1230 & yes & $\begin{array}{l}\text { South Sweden } \\
\text { (Småland), } \\
\text { North Finland }\end{array}$ & $1918-1956$ & 2 \\
\hline $\begin{array}{l}\text { River } \\
\text { Ljungan }\end{array}$ & Ljungan & - & yes & $\begin{array}{l}\text { South Sweden } \\
\text { (Småland) }\end{array}$ & $\begin{array}{c}\text { Beginning of } \\
1900\end{array}$ & 1 \\
\hline $\begin{array}{c}\text { Lake } \\
\text { Tomtasjön }\end{array}$ & $\begin{array}{l}\text { Skeboån/Bro- } \\
\text { strömmen }\end{array}$ & $<50$ & no & & & 1 \\
\hline $\begin{array}{l}\text { Lake } \\
\text { Bornsjön }\end{array}$ & Norrström & 679 & no & & & 1 \\
\hline $\begin{array}{c}\text { Lake } \\
\text { Lockvattnet }\end{array}$ & Norrström & 599 & no & & & $\begin{array}{l}2 \text { (different } \\
\text { years) }\end{array}$ \\
\hline $\begin{array}{l}\text { Lake } \\
\text { Aspen }\end{array}$ & Norrström & 130 & no & & & 1 \\
\hline $\begin{array}{l}\text { Gotland } \\
\text { (pond) }\end{array}$ & Coastal & $<50$ & yes & $\begin{array}{l}\text { South Sweden } \\
\text { (Småland) }\end{array}$ & Late 1800 & 1 \\
\hline $\begin{array}{c}\text { River } \\
\text { Nättrabyån }\end{array}$ & Nättrabyån & - & no & & & 1 \\
\hline $\begin{array}{c}\text { Lake } \\
\text { Tjörnarpasjön }\end{array}$ & Helge å & 59 & no & & & 1 \\
\hline $\begin{array}{l}\text { Lake } \\
\text { Teåkerssjön }\end{array}$ & Göta älv & 399 & no & & & 1 \\
\hline $\begin{array}{l}\text { River } \\
\text { Malån }\end{array}$ & Göta älv & - & no & & & $\begin{array}{c}3 \text { (different } \\
\text { years) }\end{array}$ \\
\hline $\begin{array}{l}\text { Lake } \\
\text { Gransjön }\end{array}$ & Göta älv & $<50$ & no & & & 1 \\
\hline $\begin{array}{c}\text { River } \\
\text { Åsebyälven }\end{array}$ & Göta älv & - & no & & & 3 \\
\hline Molkom & Göta älv & $<50$ & $\begin{array}{l}\text { yes (newly } \\
\text { established } \\
\text { pond) }\end{array}$ & $\begin{array}{c}\text { Öland } \\
\text { (Småland) }\end{array}$ & $\begin{array}{c}1990 \\
\text { (Late 1800) }\end{array}$ & 1 \\
\hline
\end{tabular}

The entire nuclear ribosomal ITS region was amplified and partially sequenced for 18 specimens from four Swedish $A$. astacus populations (Tjörnarpasjön (tj), Teåkerssjön (te), Tomtasjön (to) and Råneälven (rå)), one specimen from Montenegro and one specimen of $P$. leniusculus. 


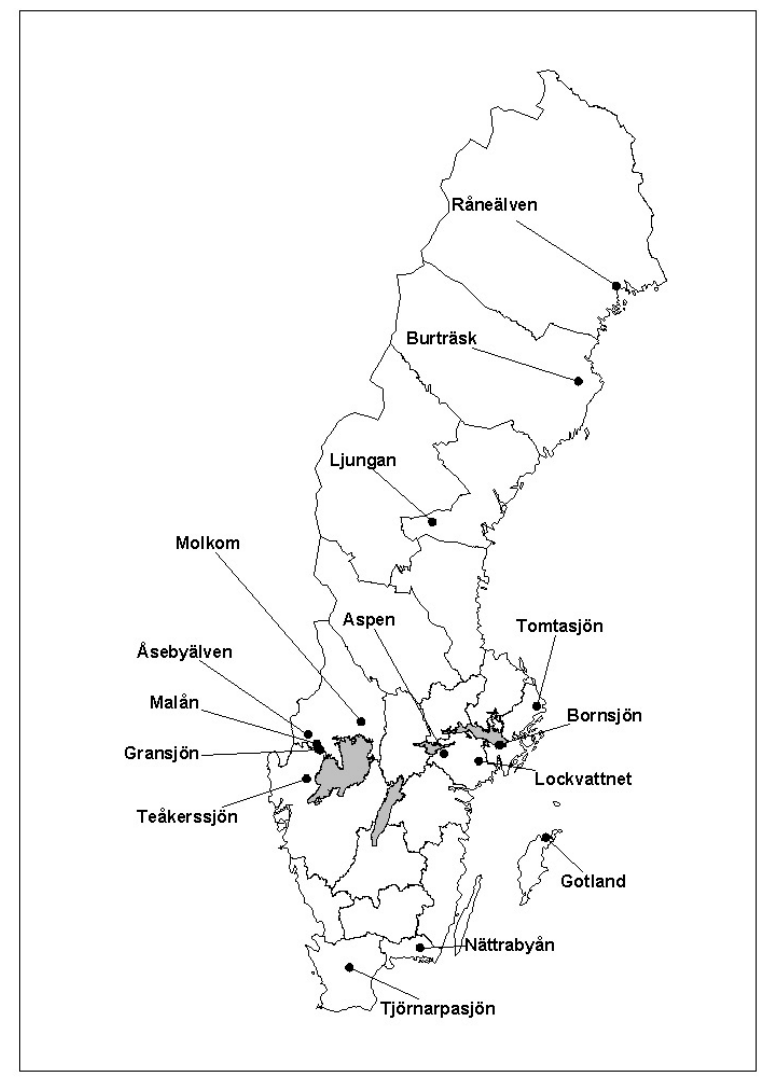

\section{Figure 1}

Map of Sweden with names and locations for the crayfish populations studied.

\section{Figure 1}

Carte géographique de la Suède avec les noms et les localisations des populations d'écrevisse étudiées.

\section{DNA extraction}

A total of 642 specimens were subjected to fragment analysis as described below. All primers used are listed, with references, in Table III and their locations in the ribosomal repeat are shown in Figure 2.

\section{Table III}

Primers used in the PCR and sequence reactions.

\section{Tableau III}

Amorces de PCR et de séquençage utilisées.

\begin{tabular}{llcl} 
Primer & Sequence 5'-3' direction & Position in Figure 2 & Reference \\
\hline ITS5 & ggaagtaaaagtcgtaacaagg & a & WHITE et al., 1990 \\
P1 & aagtcgtaacaaggttccgtaggtg & b & ELDENÄS et al., 1998 \\
Asa1F & tcactccgtcagcagtgagtcgct & c & this study \\
Asa1R & gagtcagctagacgtgcagcctaggccc & d & this study \\
Asa2R & ttatcggtgccgcatctgcctgccct & e & this study \\
ITS4 & tcctccgcttattgatatgc & $\mathrm{f}$ & WHITE et al., 1990
\end{tabular}




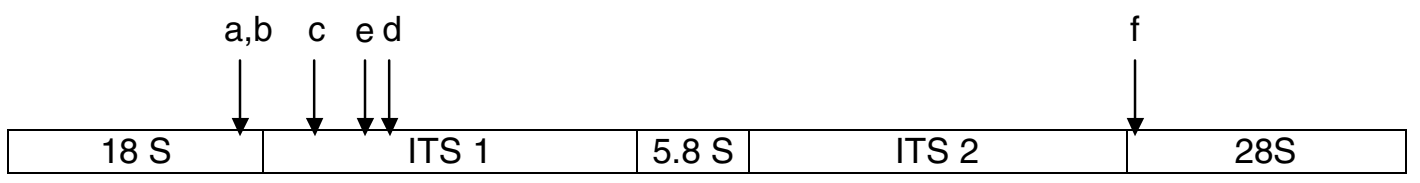

Figure 2

Schematic picture of the ribosomal gene with the position of the primers indicated.

\section{Figure 2}

Image schématique du gène ribosomique indiquant les positions des amorces utilisées.

DNA was extracted from frozen material. For the first four populations (approx. 200 specimens) a small portion of the tail muscle was placed in $500 \mu \mathrm{l}$ buffer containing $100 \mathrm{mM}$ Tris- $\mathrm{HCl}, \mathrm{pH} 8.5,50 \mathrm{mM}$ EDTA, $2 \%$ SDS, $20 \mathrm{mM} \mathrm{NaCl}$ and $5 \mu$ proteinase $\mathrm{K}$ (20 mg/mL), and lysed at either $56^{\circ} \mathrm{C}$ for 3 hours, or $37^{\circ} \mathrm{C}$ overnight. The tubes were centrifuged for $5 \mathrm{~min}$ at $7000 \mathrm{rpm}$. The DNA in the supernatant was precipitated in $95 \%$ ethanol and dissolved overnight in approx. $100 \mu \mathrm{l} 1 \mathrm{x}$ TE (1 mM Tris, $0.1 \mathrm{mM}$ EDTA). The DNA concentration was not measured previous to the PCR reactions, but $0.5 \mu \mathrm{l}$ of the extracts turned out to be optimal.

For all other specimens we used a simplified method for the DNA extraction. A clean, wooden toothpick was inserted into a freshly opened leg joint of the frozen crayfish and then immediately immerged into $30 \mu \mathrm{l}$ of $1 \mathrm{x}$ TE. The sample was then frozen and thawed once before spinning down the cell debris for 60 seconds. $3 \mu$ of the supernatant was used in the subsequent PCR reactions. We could not detect any differences in quality between the two methods of DNA extractions. The simplified extraction method works equally well on frozen, fresh, boiled or ethanol preserved tissue.

\section{Sequencing}

PCR was performed using the primer P1 annealing at the 3 ' end of $18 \mathrm{~S}$ and the primer ITS4 annealing at the 5' end of 28S. For the reactions we used " Ready-to-go PCR beads " from Amersham Pharmacia Biotech, SE-751 84 Uppsala, Sweden. The PCR cycling was performed with an initial cycle at $94^{\circ} \mathrm{C}$ for 5 min followed by 30 cycles at $94^{\circ} \mathrm{C}$ for $30 \mathrm{~s}, 50^{\circ} \mathrm{C}$ for $30 \mathrm{~s}, 72^{\circ} \mathrm{C}$ for $30 \mathrm{~s}$ and a final cycle at $72^{\circ} \mathrm{C}$ for 5 min. PCR products were purified using QIAquick PCR purification kit from Qiagen prior to sequencing. Sequencing reactions were then performed using Amersham's "ThermoSequenase Fluorescent labeled primer sequencing kit »(Amersham Pharmacia Biotech, SE-751 84 Uppsala, Sweden) with the CY-5 labeled primers ITS4 and ITS5, respectively, and the following cycling profile: one cycle at $95^{\circ} \mathrm{C}$ for $2 \mathrm{~min} ; 30$ cycles at $95^{\circ} \mathrm{C}$ for $30 \mathrm{~s}, 55^{\circ} \mathrm{C}$ for $30 \mathrm{~s}$ and $70^{\circ} \mathrm{C}$ for $60 \mathrm{~s}$. The sequencing was performed on an ALFExpress automated sequencer from Pharmacia Biotech.

\section{Fragment analyses}

Based on the obtained sequences two additional primers, Asa1F and Asa1R, were designed to amplify a portion of the ITS1 region, at a distance of approximately $40 \mathrm{bp}$ on each sides of a short tandem repeat. One of the primers was labeled with CY-5. The PCR reactions were performed with one initial cycle for $5 \mathrm{~min}$ at $94^{\circ} \mathrm{C}$, followed by 30 cycles at $94^{\circ} \mathrm{C}$ for $30 \mathrm{~s}, 60^{\circ} \mathrm{C}$ for $30 \mathrm{~s}, 72^{\circ} \mathrm{C}$ for $60 \mathrm{~s}$ and 1 cycle at $72^{\circ} \mathrm{C}$ for $5 \mathrm{~min} .0 .5-1.5 \mu \mathrm{l}$ of the 
unpurified products were loaded onto a $6 \%$ Long Ranger gel and fragments were separated by electrophoreses on the ALFExpress automated sequencer. Fragment size was determined using the «Fragment Manager » from Pharmacia Biotech. We used a CY5 labeled external size marker ranging between $50-500$ bp in 50 bp intervals, and two internal size markers, 50 and 250 bp mixed into the individual samples. All fragment patterns were carefully visually inspected. Allele scoring was performed independently, in parallel, by the different authors. Faint, occasional fragments, or fragments interpreted as stutter-bands were not scored.

During the initial fragment analysis several steps were performed in order to ensure that results were reproducible. 1) Aliquots from the same sample were loaded onto different gels. 2) Several PCR reactions were made from the same extraction, in some cases after a time span of more than a year. 3) One of the primers, Asa1R, was replaced with an alternative primer, Asa2R, yielding shorter fragments. 4) PCR was done using either total genomic DNA, or the amplified entire ITS region as template. 5) The specificity of the Asa1F and Asa1R primers was investigated by attempting PCR on related crustaceans as well as on humans.

\section{Population Divergence Test}

The Population Divergence Test employs a measure $d_{i j}$ of the difference between populations $i$ and $j$ in the frequencies of the fragments. Let $f_{i k}$ denote the frequency of fragment $k$ in (the sample from) population $i$. Then:

$$
d_{i j}=\sum_{k}\left|f_{i k}-f_{j k}\right| /\left(f_{i k}+f_{j k}\right)
$$

To evaluate the significance of $d_{i j}$ we make use of the idea that, under the null hypothesis of no difference between populations, any of the specimens could equally well have been sampled from either population. The distribution of $d_{i j}$ under the null hypothesis can accordingly be obtained by simulation, using random reallocation of specimens. Let $n_{i}$ and $n_{j}$ stand for the numbers of specimens in samples $i$ and $j$, respectively. The value of $d_{i j}$ is first computed for the actual pair of samples, then for 100000 pairs of pseudosamples. Each pair of pseudosamples is obtained by randomly assigning the collection of $n_{i}+n_{i}$ specimens into two new lots with $n_{i}$ and $n_{j}$ specimens. The observed $d_{i j}$ is considered to show a significant difference between the populations if it is larger than $95 \%$ of the $d$ values found from random reallocations of samples $i$ and $j$. For the calculations we used the program PDT, developed by J.S. Farris (FARRIS, 2000).

\section{RESULTS}

Amplification of the entire ITS region resulted in very long fragments as estimated from an agarose gel. The approximate values were $2000 \mathrm{bp}$ for $A$. astacus, $2300 \mathrm{bp}$ for A. leptodactylus, $1600 \mathrm{bp}$ for $P$. Borealis, $1800 \mathrm{bp}$ for $N$. norvegicus and $2100 \mathrm{bp}$ for $P$. leniusculus.

Sequencing of $A$. astacus proved difficult. We were only able to read short sequences (220-450 bp) due the presence of two dinucleotide insertions in ITS1, situated approximately $220 \mathrm{bp}$ and $460 \mathrm{bp}$ from the 5 ' end, respectively. Both consisted of perfect dinucleotide GA-repeats. When comparing sequences from four different populations we found that the second microsatellite insertion seemed to be constant in length. In contrast, the first appeared constant within each population, but varied distinctly in length between them. It was, however, difficult to exactly identify the number of dinucleotides due to the 
poor quality of some sequences. Apart from the length differences in the first GA-repeat we found no sequence variation among the 18 investigated individuals.

Amplification using primers Asa1F and Asa1R was always successful for DNA from $A$. astacus. No PCR product was ever obtained when material from $A$. leptodactylus, $P$. borealis, $N$. norvegicus, $P$. leniusculus or humans were used as templates. The fragment analysis revealed that there was more intragenomic variation than could be detected from inspection of the directly sequenced PCR-products. Altogether 17 different fragments were identified, ranging in size between $162-210 \mathrm{bp}$. Many specimens had at least two alleles, but in some cases we found up to four, or even five alleles. Longer fragments with many dinucleotide repeats often had accompanying bands, which we interpreted as stutterbands, resulting from replication slippage during PCR.

Fragment patterns from the same individual could be reproduced with great consistency: different DNA extraction methods yielded identical patterns as did duplicates loaded on different gels, or originating from different PCR reactions. Also, the specifically designed primers Asa1F and Asa1R produced the same patterns regardless of if total genomic DNA or the amplified ITS region were used as templates.

Table IV summarizes the findings from the fragment analysis. Different populations displayed distinctly different fragment patterns. Populations like Teåkerssjön (te), Gransjön (gr) and Malån (ma) showed a small variation with only 1-2 genotypes, involving 1 or 2 alleles. Others, such as Burträsk (bu), Molkom (mo), and Tomtasjön (to), displayed a high diversity with 18, 17 and 15 genotypes, respectively, involving 7-8 alleles each. Intragenomic variation was encountered in all populations except Teåkerssjön. Many individuals were found to have two or three alleles, and in some populations (Burträsk (bu), Lockvattnet (lo), Molkom, Råneälven (rå), Åsebyälven (ås)) even four, or five alleles occurred.

The two Yugoslavian populations, Crupaco $(\mathrm{mc})$ and Slano $(\mathrm{ms})$ revealed genotypes that were not found in the Swedish material.

The population divergence test shows that there are highly significant differences $(p<0.0028)$ between most Swedish populations. Exceptions to this were Aspen (as) / Bornsjön (bo) ( $p=0.5456)$, Gransjön / Malån / Teåkerssjön ( $p=0.2763,0.4968,0.5305)$, and the two Montenegro populations Crupaco / Slano $(p=0.2363)$. See Table V.

\section{DISCUSSION}

\section{The ITS region as a genetic marker}

The ITS region has, so far, received less attention from zoologist than from botanists or mycologists. In plants and fungi reported lengths of this region usually range between 550-800 bp. In animals the variations seems greater and more complex. When we first started amplifying the ITS region of $A$. astacus we were surprised at the size of the obtained fragments, which were approximately $2000 \mathrm{bp}$ long in $A$. astacus and approximately $2300 \mathrm{bp}$ in $A$. leptodactylus. However, some recent studies have reported similar observations. HARRIS and CRANDALL (2000) found unexpectedly long fragments when investigating the ITS region of the crayfish genera Orconectes and Procambarus. VON DER SCHULENBURG et al. (2001) found extremely long sequences in coccinellid beetles, where ITS1 alone could be almost $2700 \mathrm{bp}$ long. In these cases, including our study, most of the increase in length is due to the presence of microsatellite-like insertions. 
Table IV

The occurrence of different genotypes (combinations of fragment lengths) in the 17 populations studied. Abbreviations as in Table $\mathrm{I}$.

Tableau IV

Apparition des différents génotypes (combinaisons de longueurs de fragments) dans les 17 populations étudiées. Les abréviations utilisées sont identiques à celles du Tableau $\mathrm{I}$.

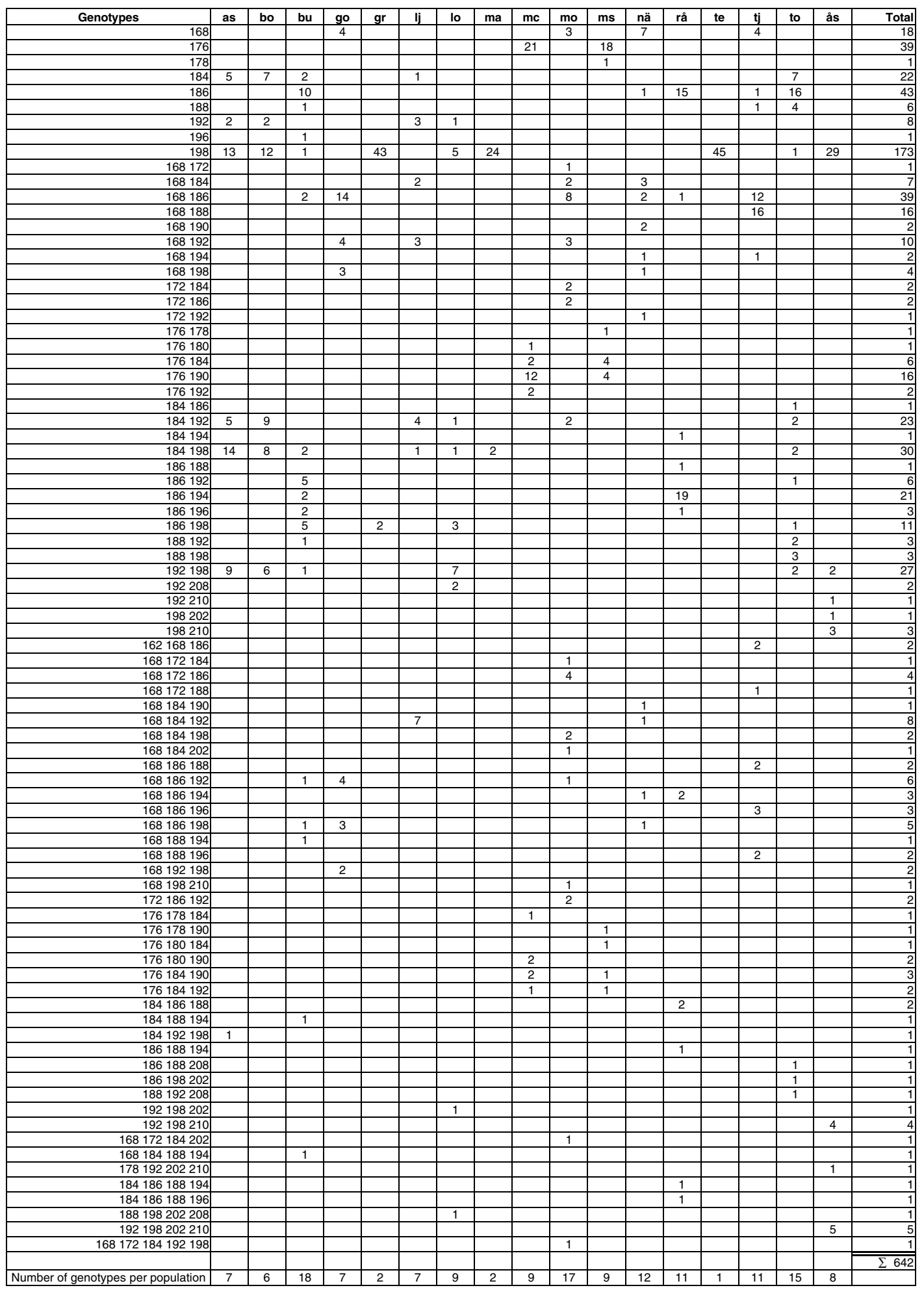


Table V

Results from the population divergence test. Numbers shown represent p-values for differences between populations. Bold numbers indicates differences that are not significant. Zeros indicate $p<0.00005$. Abbreviations as in Table $I$.

Tableau V

Résultats du test de divergence des populations. Les nombres représentent les p-valeurs pour les différences entre les populations. Les différences qui ne sont pas significatives sont indiquées par des nombres en gras. Les zéros indiquent une valeur de $p<0,00005$. Les abréviations utilisées sont identiques à celles du Tableau I.

\begin{tabular}{|c|c|c|c|c|c|c|c|c|c|c|c|c|c|c|c|c|c|c|}
\hline Locality & & as & bo & bu & go & gr & lj & lo & ma & mo & $\mathrm{mc}$ & $\mathrm{ms}$ & nä & rå & te & $\mathrm{tj}$ & to & ås \\
\hline Aspen & as & - & & & & & & & & & & & & & & & & \\
\hline Bornsjön & bo & 0.5456 & - & & & & & & & & & & & & & & & \\
\hline Burträsk & bu & 0 & 0 & - & & & & & & & & & & & & & & \\
\hline Gotland & go & 0 & 0 & 0 & - & & & & & & & & & & & & & \\
\hline Gransjön & gr & 0 & 0 & 0 & 0 & - & & & & & & & & & & & & \\
\hline Ljungan & lj & 0 & 0 & 0 & 0 & 0 & - & & & & & & & & & & & \\
\hline Lockvattnet & lo & 0.0001 & 0 & 0 & 0 & 0.0011 & 0 & - & & & & & & & & & & \\
\hline Malån & ma & 0 & 0 & 0 & 0 & 0.2763 & 0 & 0.0028 & - & & & & & & & & & \\
\hline Molkom & mo & 0 & 0 & 0 & 0 & 0 & 0 & 0 & 0 & - & & & & & & & & \\
\hline Montenegro, Crupaco & $\mathrm{mc}$ & 0 & 0 & 0 & 0 & 0 & 0 & 0 & 0 & 0 & - & & & & & & & \\
\hline Montenegro, Slano & $\mathrm{ms}$ & 0 & 0 & 0 & 0 & 0 & 0 & 0 & 0 & 0 & 0.2363 & - & & & & & & \\
\hline Nättrabyån & nä & 0 & 0 & 0.0001 & 0 & 0 & 0 & 0 & 0 & 0.0013 & 0 & 0 & - & & & & & \\
\hline Råneälven & rå & 0 & 0 & 0.0010 & 0 & 0 & 0 & 0 & 0 & 0 & 0 & 0 & 0 & - & & & & \\
\hline Teåkerssjön & te & 0 & 0 & 0 & 0 & 0.4968 & 0 & 0 & 0.5305 & 0 & 0 & 0 & 0 & 0 & - & & & \\
\hline Tjörnarpasjön & $\mathrm{tj}$ & 0 & 0 & 0 & 0 & 0 & 0 & 0 & 0 & 0 & 0 & 0 & 0.0001 & 0 & 0 & - & & \\
\hline Tomtasjön & to & 0 & 0 & 0.0004 & 0 & 0 & 0 & 0.0002 & 0 & 0 & 0 & 0 & 0 & 0 & 0 & 0 & - & \\
\hline Åsebyälven & ås & 0 & 0 & 0 & 0 & 0 & 0 & 0.0010 & 0.0001 & 0 & 0 & 0 & 0 & 0 & 0 & 0 & 0 & - \\
\hline
\end{tabular}


Similar insertions have previously been found in animal nuclear ribosomal regions, e.g. in humans (GONZALES et al., 1990), beetles (VOGLER and DESALLE, 1994), flies (MUKABAYIRE et al., 1999) and dragonflies (R. HOVMÖLLER, pers. comm.). Their presence is not always correlated with long ITS sequences, in Cicindela dorsalis the ITS1 sequence is instead unusually short, only $250-260$ bp (VOGLER and DESALLE, 1994). The nature of the insertions varies. VON DER SCHULENBURG et al. (2001) found repetitive elements with long repeat units concentrated at the middle of ITS1. VOGLER and DESALLE (1994) found strings of adenine, as well as AT-repeats in the ITS1. In our study we identified two perfect GA-repeats of varying length $(G A)_{8-29}$, near the 5' end of the ITS1 region in A. astacus. This is in agreement with HARRIS and CRANDALL (2000) who also found two such repeats in ITS1, as well as a more complex trinucleotide repeat situated near the spacer's 3' end.

Intragenomic variation among ribosomal repeats is known from plants and animals, and has also been reported from fungi. HARRIS and CRANDALL (2000) found considerable intragenomic variation in Procambarus and Orconectes, even to the extent that variation within individuals exceeded that between different species. We also found considerable intragenomic variation, with up to 4-5 alleles in single individuals, when investigating the microsatellite amplified by Asa1F and Asa1R in A. astacus. All variation appears to be confined to this microsatellite region, at least we did not find any other sequence variation in the ITS sequences obtained from 18 individuals from four populations. However, as explained in Material and methods, we were only able to read short (240-400 bp) ITS1 DNA sequences, and it is possible that there could be variation in the 3 ' end that we were not able to detect.

The homogenization of members of the same multigene family is generally referred to as concerted evolution (ZIMMER et al., 1980). The small subunit, or 18S, of the rDNA repeat, shows a high degree of homogenization, but in the spacer regions polymorphisms are not uncommon. That such polymorphisms may persist for a long time can be seen in the study of SUH et al. (1993), whereas in other studies, e.g. HILLIS and DIXON (1991) polymorphisms appear more short-lived. At this point we know little about homogenization processes in $A$. astacus. The extensive intragenomic variation found in Burträsk and Tomtasjön could be the result of less efficient homogenization mechanisms perhaps as a result of multiple chromosome locations. Another explanation for the variation could be recent introductions of crayfish from other localities into the population. Multiple stockings have occurred in Burträsk, whereas recent stockings are not known for Tomtasjön. It will be interesting to monitor these populations over a more extended period of time to see if the variation is maintained or decreased.

HARRIS and CRANDALL (2000) also pointed out that, at least to their knowledge, intragenomic variation had always been detected when searched for. It seems very reasonable to assume that intragenomic variation is often undetected since most studies are based on direct sequencing of PCR products. However, there are results (SUH et al., 1993) that indicate that in some taxa intragenomic variation is rare or absent. It is interesting to note that even though ribosomal genes are ubiquitous they seem to have different characteristics in different organismal groups. The presence of microsatellite insertions in the ITS1 as found in this study seem to be fairly common in arthropods and perhaps also in other animal groups, but must be rare or absent in flowering plants where the ITS region has been sequenced quite extensively. It seems likely that also the mechanisms for concerted evolution may vary in different groups, and that caution should be taken before making general assumption based on studies in restricted taxonomic groups.

Multicopy genes pose a problem for phylogenetic analyses. For phylogenetic reconstruction it is vital that the characters used are homologous. Unless the rate of homogenization far exceeds that of speciation, assessments of homology are difficult to 
make for tandemly repeated genes (HILLIS and DAVIS, 1988). That this condition is met is generally assumed for the small subunit (18S) of the ribosomal repeat, which is one of the most widely used molecules in phylogenetic studies. For the internal transcribed spacers the situation is obviously more complicated. This was discussed in detail by HARRIS and CRANDALL (2000) who suggested that intragenomic variation should be investigated more carefully before using ITS sequences in phylogenetic studies. This is indeed good advice, and we do not propose that the tandem repeat length variation we found in $A$. astacus is appropriate to use for hypotheses of relationships among populations since, at this point, we have no means to distinguish between orthologous and paralogous repeats.

Repeated sequences evolving in concert are considered inappropriate for quantifying long-term genetic flow, effective population size, and deviations from Hardy-Weinberg equilibrium (DOWLING et al., 1996). HARRIS and CRANDALL (2000) point out that when using hybridization techniques microsatellites in multicopy regions such as the rDNA will be preferentially found and suggest that sequencing of multiple clones from single individuals should be standard practice to avoid spurious results. This is certainly to be recommended over testing for deviation from Hardy-Weinberg equilibrium because even though multicopy genes can not be assumed to have a Mendelian inheritance they need not significantly deviate from Hardy-Weinberg equilibrium.

\section{Genetic variation in Swedish crayfish populations}

Four of the 15 Swedish populations were sampled on more than one occasion. Of these, lake Malån that was even sampled different years, still had only two genotypes, while the Burträsk population displayed 18 different genotypes. Thus the patterns found in this study does not seem to be confounded by the number of sampling occasions.

There are no obvious patterns in the number of genotypes or alleles found in the populations and the known history of stockings. Some of the populations, like Tomtasjön, Nättrabyån and Tjörnarpasjön, with no known stockings, have a high number of genotypes, while some of the populations with known stockings (Ljungan and Gotland) have comparatively few genotypes. Likewise lake size, that should correlate to population size, does not seem to influence the number of genotypes found. We find that even though there is a considerable intragenomic variation we still find significant differences between most of the crayfish populations.

The populations that do not differ significantly share some properties. The distance between the populations in Malån and Gransjön is only $11 \mathrm{~km}$ and both populations belong to the same small drainage system. Some gene flow between these two populations is thus likely. The distance between Gransjön and Teåkerssjön is $49 \mathrm{~km}$ and the lakes are separated by another drainage system. All these three populations belong to the same main river system. No stockings are known to have occurred for these localities. The populations in Aspen and Bornsjön, that cannot be genetically distinguished from each other, are $91 \mathrm{~km}$ apart both belonging to the same main river system. No stockings are known for these two lakes. The same holds for the two Montenegro populations, where Crupaco and Slano are only a couple of kilometers apart and both belong to the River Zeta drainage. Both Yugoslavian populations show a unique fragment pattern, not found in any of the Swedish populations. Since crayfish fishery and trade has no strong tradition in Yugoslavia, introductions or translocations by man are not likely to have occurred. The genetic differences found between all the other populations could be explained by lack of gene flow due to larger geographic distances between them.

Even if we find differences between populations with the genetic markers used in this study, we do not know if this is correlated to differences in morphology or physiology between the populations. One of the authors (L. EDSMAN) has however investigated 
physiological growth rate by quantifying RNA content in tail muscle for the populations from Teåkerssjön and Nättrabyån and found a significant difference in growth rate between the populations (unpublished). This is so far the only indication that local adaptations in A. astacus may occur.

\section{Implications for management}

In Sweden a management and action plan for the conservation of the noble crayfish has been presented (FISKERIVERKET and NATURVÅRDSVERKET, 1998). At the moment regional restocking programs are being performed and planned to reintroduce crayfish into waters from which they have disappeared and to enhance existing populations. The crayfish used in the program is checked for diseases and the recommendation in the plan is also to use local stocking material. This is however only a precautious recommendation since information on local adaptations and genetic diversity between populations has not been available and since the earlier studies did not show genetic differentiation. Since health checked local stocking material is not readily available, in practice crayfish from southern Sweden is introduced into waters in the north of the country, sometimes being moved up to $1000 \mathrm{~km}$. This practice could result in the disappearance of locally adapted populations. It is therefore urgent to continue to monitor the genetics and eventual local adaptations of the noble crayfish in the country. The knowledge gained should then be applied to the continued work with the conservation of the species and the unit to conserve may not only be the species, but also genetically distinct locally adapted populations. A variety of genetic markers have been used to reveal genetic diversity between $A$. pallipes populations with implications for conservation and management plans (SOUTY-GROSSET et al., 1999; GRANDJEAN and SOUTY-GROSSET, 2000). The markers developed in this study may be a practical tool in this context for $A$. astacus.

\section{ACKNOWLEDGEMENTS}

We would like to thank Johan Dannewitz, Birgitta Ekstrand, Anders Götherström and Leif Johansson for valuable help and support in our work, Vincent Rousset for helping us with the French translation and three anonymous reviewers for valuable comments on the manuscript. We also thank the many providers of crayfishes used in our analyses, and for the information about the crayfish populations. The study was supported by grants from The Swedish Council for Forestry and Agricultural Research and from The Carl Trygger Foundation.

\section{REFERENCES}

AGERBERG A., 1990. Genetic variation in three species of freshwater crayfish; Astacus astacus L., Astacus leptodactylus Aesch., and Pacifastacus leniusculus (Dana), revealed by isozyme electrophoresis. Hereditas, 113, 101-108.

BALDWIN B.G., SANDERSON M.J., PORTER J.M., WOJCIECHOWSKI M.F., CAMPBELL C.S., DONOGHUE M.J., 1995. The ITS region of nuclear ribosomal DNA: a valuable source of evidence of angiosperm phylogeny. Annals of the Missouri Botanical Garden, 82, 247-277.

CRANDALL K.A., 1997 Genetic variation within and among crayfish species. Freshwater Crayfish, 11, 135-145.

DOWLING T.E., MORITZ C., PALMER J.D., RIESEBERG L.H., 1996. Nucleic Acids III: Analysis of fragments and restriction sites. In : HILLIS D.M., MORITZ C. and MABLE B.K. (Eds.), Molecular Systematics, Sinauer Associates, Inc. Sunderland, Massachusetts. 
ELDENÄS P., ANDERBERG A.A., KÄLLERSJÖ M., 1998. Molecular phylogenetics of the tribe Inuleae s. str. (Asteraceae) based on ITS sequences of nuclear ribosomal DNA. Plant Systematics and Evolution, 210, 159-173.

FARRIS J.S., 2000. PDT. Computer program and documentation. Swedish Museum of Natural History, Stockholm, Sweden.

FISKERIVERKET, 1993. Ways of increasing populations of noble crayfish Astacus astacus in Swedish fresh waters. Information from the Institute of Freshwater Research, Drottningholm, 2, 1993, 1-66 (in Swedish with English summary).

FISKERIVERKET and NATURVÅRDSVERKET, 1998. Action plan for the restoration of the noble crayfish in Sweden. JÄRVI T., THORELL L. (Eds.), Fiskeriverket and Naturvårdsverket, Göteborg and Stockholm (in Swedish).

FEVOLDEN S.E., HESSEN D.O., 1989. Morphological and genetic differences among recently founded populations of noble crayfish (Astacus astacus). Hereditas, 110, 149-158.

FETZNER J.W., CRANDALL K.A., 1999. Genetic variability within and among populations of the golden crayfish (Orconectes luteus): a comparison using amplified fragment length polymorphisms (AFLPs) and mitochondrial 16s gene sequences. Freshwater Crayfish, 12, 396-412.

GÄRDENFORS U. (ed.), 2000. The 2000 red list of Swedish species. ArtDatabanken, SLU, Uppsala.

GARDES M., BRUNS T.D., 1993. ITS primers with enhanced specificity for basiodiomycetes- application to the identification of mycorrhiza and rusts. Molecular Ecology, 2, 113-118.

GONZALES I.S., SYLVESTER J.E., SMITH T.F., STAMBOLIAN D., SCHMICKEL R.D., 1990. Ribosomal RNA gene sequences and hominoid phylogeny. Molecular Biology and Evolution, 7, 203-219.

GOUIN N., GRANDJEAN F., SOUTY-GROSSET C., 2000. Characterization of microsatellite loci in the endangered freshwater crayfish Austropotamobius pallipes (Astacidae) and their potential use in other decapods. Molecular Ecology, 9, 629-644.

GOUIN N., GRANDJEAN F., BOUCHON D., REYNOLDS J.D., SOUTY-GROSSET C., 2001. Population genetic structure of the endangered freshwater crayfish Austropotamobius pallipes, assessed using RAPD markers. Heredity, 87, 80-87.

GRANDJEAN F., SOUTY-GROSSET C., 2000. Mitochondrial DNA variation and population genetic structure of the white-clawed crayfish, Austropotamobius pallipes pallipes. Conservation Genetics, 1, 309-319.

GRANDJEAN F., SOUTY-GROSSET C., RAIMOND R., HOLDICH D.M., 1997. Geographical variation of mitochondrial DNA between populations of the whiteclawed crayfish Austropotamobius pallipes. Freshwater Biology, 37, 493-501.

GROOMBRIDGE B., 1994. IUCN Red list of Threatened Animals. IUCN, Switzerland and Cambridge, UK.

HARRIS D.J., CRANDALL K.A., 2000. Intragenomic variation within ITS1 and ITS2 of freshwater crayfishes (Decapoda: Cambaridae): implications for phylogenetic and microsatellite studies. Molecular Biology and Evolution, 17, 284-291.

HEDGECOCK D., TRACEY M.I., NELSON K., 1982. Genetics. In : BLISS D.E. (ed.), The Biology of the Crustacea, Gland, Switzerland and Cambridge, UK.

HILLIS D.M., DAVIS S.K., 1988. Ribosomal DNA: Intraspecific polymorphism, concerted evolution and phylogeny reconstruction. Systematic Zoology, 32, 63-66.

HILLIS D.M., DIXON M.T., 1991. Ribosomal DNA: Molecular evolution and phylogenetic inference. Quarterly Review of Biology, 66, 41-453.

LARGIADER C.R., HERGER F., LÖRTSCHER M., SCHOLL A., 2000. Assessment of natural and artificial propagation of the white-clawed crayfish (Austropotamobius pallipes species complex) in the Alpine region with nuclear and mitochondrial markers. Molecular Ecology, 9, 25-37.

LÖRTSCHER M., STUCKI T.P., CLALÜNA M., SCHOLL A., 1997. Phylogeographic structure of Austropotamobius pallipes populations in Switzerland. Bull. Fr. Pêche Piscic., 347, 649-661. 
MUKABAYIRE O., BOCCOLINI D., LOCHOUARN L., FONTENILLE D., BESANSKY N.J., 1999. Mitochondrial and ribosomal internal transcribed spacer (ITS2) diversity of the African malarial vector Anopheles funestus. Molecular Ecology, 8, 289-297.

ODELSTRÖM T., JOHANSSON S., 1999. Noble crayfish farming in northern Sweden biological and economic prerequisites. Information from the Institute of Freshwater Research, Drottningholm, 1, 1993, 7-58.

POLANCO C., GONZALES A.I., DE LA FUENTE A., DOVER G., 1998. Multigene family of ribosomal DNA in Drosophila melanogaster reveals contrasting patterns of homogenization for IGS and ITS spacer regions. A possible mechanism to solve this paradox. Genetics, 149, 243-256.

SCHILTHUIZEN M., HOEKSTRA R., GITTENBERGER E., 2001. The " rare allele phenomenon » in a ribosomal spacer. Molecular Ecology, 10, 1341-1345.

SCHULZ R., 2000. Status of the noble crayfish Astacus astacus (L.) in Germany: monitoring protocol and the use of RAPD markers to assess the genetic structure of populations. Bull. Fr. Pêche Piscic., 356, 123-138.

SKURDAL J., TAUGBØL T., BURBA A., EDSMAN L., SÖDERBACK B., STYRISHAVE B., TUUSTI J., WESTMAN K., 1999. Crayfish introduction in the Nordic and Baltic countries. In : GHERARDI F. and HOLDICH D.M. (Eds.), Crayfish in Europe as alien species - How to make the best of a bad situation?, 193-219. Balkema, Rotterdam.

SOUTY-GROSSET C., GRANDJEAN F., RAIMOND R., FRELON M., DEBENEST C., BRAMARD M., 1997. Conservation genetics of the white-clawed crayfish Austropotamobius pallipes: the usefulness of the mitochondrial DNA marker. Bull. Fr. Pêche Piscic., 347, 677-692.

SOUTY-GROSSET C., GRANDJEAN F., GOUIN N., 1999. Molecular genetic contributions to conservation biology of the European native crayfish Austropotamobius pallipes. Freshwater Crayfish, 12, 371-386.

SUH Y., THIEN L.B., REEVE H.E., ZIMMER E.A., 1993. Molecular evolution and phylogenetic implications of internal transcribed spacer sequences of ribosomal DNA in Winteraceae. American Journal of Botany, 80, 1042-1955.

SVÄRDSON G., 1972. The predatory impact of Eel (Anguilla anguilla L.) on populations of crayfish (Astacus astacus L.). Rep. Inst. Freshw. Res., Drottningholm, 52, 149-191.

TANG J., TOE L., BACK C., UNNASCH T.R., 1996. Intra-specific heterogeneity of the rDNA internal transcribed spacer in the Simulium damnosum (Diptera: Simuliidae) complex. Molecular Biology and Evolution, 13, 244-252.

VOGLER A.P., DESALLE R., 1994. Evolution and phylogenetic information content of the ITS-1 region in the tiger beetle, Cicindela dorsalis. Molecular Biology and Evolution, $11,393-405$.

VON DER SCHULENBURG J.H., HANCOCK J.M., PAGNAMENTA A., SLOGGETT J.J., MAJERUS M.E., HURST G.D., 2001. Extreme length and length variation in the first ribosomal internal transcribed spacer of ladybird beetles (Coleoptera: Coccinellidae). Molecular Biology and Evolution, 4, 648-660.

WHITE T.J., BRUNS T.D., LEE S., TAYLOR J.W., 1990. Amplification and direct sequencing of fungal ribosomal genes for phylogenetics. In : INNIS M.A.D., GELFAND H., SNINSKY J.J. and WHITE T.J. (Eds.), PCR Protocols, Academic Press, San Diego, CA.

ZIMMER E.A., MARTIN S.L., BEVERLY S.M., KAN Y.W., WILSON A.C., 1980. Rapid duplications and loss of genes coding for chains of hemoglobin. Proceedings of the National Academy of Science of USA, 77, 2158-2162. 